\title{
An Israeli Account Of A Near-Death Experience: A Case Study Of Cultural Dissonance
}

\author{
Henry Abramovitch, Ph.D. \\ Sackler School of Medicine, Tel Aviv University
}

ABSTRACT: The text of an Israeli near-death experience (NDE) is presented in translation from the Hebrew. This account is contrasted with the traditional Hebrew sources on NDEs or their equivalents, which formed part of the NDEr's native subculture. In the present case, the lack of congruence between the reported NDE and the expected cultural form led to intense confusion described by the NDEr. Further study is needed of folk traditions of NDEs.

In a recent study of near-death and out-of-body experiences in native Melanesians, Dorothy Counts (1983) emphasized the importance of cultural expectations in the interpretation of near-death experiences (NDEs) or of functional NDE equivalents, that is, accounts of the fate of a dying person that are based on cultural tradition rather than on specific experiences of individuals who have come close to death. For many individuals undergoing NDEs, the lack of a cultural model to help understand and process the experience adds greatly to the individual's sense of confusion and isolation. The ability to assimilate such experiences to available cultural models may assist the entry into such experiences and aid in communicating their significance subsequently.

But the presence of cultural models of NDEs, although generally helpful, need not necessarily be so: in particular, confusion may arise when the actual experience of a person near death clashes with cultural expectations. The following is a case study in which the lack of

Dr. Abramovitch is with the Sackler Faculty of Medicine, Tel Aviv University. Requests for reprints should be addressed to Dr. Abramovitch at the Department of Behavioral Science and Psychotherapy, Sackler Faculty of Medicine, Tel Aviv University, Ramat - Aviv 69 978, Tel Aviv, Israel. 
congruence between the reported NDE and the expected cultural model did lead to intense confusion.

This case study is a translation of an unsolicited personal account of an NDE written originally in Hebrew by Chaim Ralbag of Rehovot, Israel. It was written after Ralbag had a serious heart attack, and he composed it in an effort to make sense of what had happened to him when he lay hovering between life and death. At the time of this writing, Ralbag was unaware of the available literature by Raymond Moody (1975), Kenneth Ring (1980), and others. Indeed, he was surprised to discover that other individuals had had experiences not entirely unlike his own.

\section{Translation Of Testimony}

As I am about to recount some sensations that I experienced during my heart attack, I thought it best that I preface my account with a brief outline of my lifestyle before that event.

I was a man of home and family, with a stable life. My daily schedule was well organized. I used to go to work at 7 a.m. and return at 1:30 p.m. for lunch. As was my custom, I used to rest and nap for an hour after the meal. At 4 p.m. I would return to my activities, to my work or hobbies. My health was excellent. I had no need of doctors. Except for an ordinary case of a stuffed nose or cold, which never interfered with my set daily routine, I had no need to visit the clinic. My teaching and educational work was, for me, the major source of satisfaction and inspiration. I was close to my pupils; involved with the teaching and other staff.

I remember, in the last week before the incident, I was preoccupied preparing the inauguration of a sports field in the school, built to commemorate one of the students who fell in the Yom Kippur War. I decided to make the inauguration as modest as possible, in the presence of family, friends, and a number of public officials, representatives of the Ministry of Education and the Municipality. I recall that I was hesitant concerning the subject of my talk, which was supposed to be the central speech of the ceremony. It was hard for me to say words of comfort to the family and the bereaved parents and at the same time express the "satisfaction of achievement." I wrote, corrected, and rewrote, but my heart was heavy, for I felt that the bereavement had led to the construction of the sports field.

On Friday, March 18, I went to school with a sense of weariness. I put aside my routine work. I examined and made sure that all the details 
would be ready and in order for Sunday, March 20, the day of the ceremony. I was tired. At noon, I left school and walked to a meeting of principals. I sat and listened but I was very very tired.

At 2 p.m. I arrived home. I ate a light meal and lay down to rest. After some time, between sleep and waking, I awoke with a feeling of nausea and oppression. I got up to go to the bathroom and immediately had an attack of dizziness - circles of sparks and light danced before my eyes. My vision dulled. I held onto the door frame, shut my eyes, and said, "I will hold on until the danger is past"-but my senses became more and more clouded, the darkness deepened, and I fell down.

After a while I began to understand what I was seeing. It seemed to me that I saw those around me as if from behind a screen, and their voices reached me as if from a great distance. I understood all that they were saying, but I was apathetic to their words and I mistrusted what they told me. They said that I had had a heart attack; they said that I was in an Intensive Care Unit; that I had been unconscious for an extended period. I did not remember anything of the days I had been in that ward. I did not believe that I had been unconscious.

On the contrary, I knew that I had been fully conscious, deep in thought, and intensely active. As my condition improved, and I became stronger, I was all the more convinced that whenever I spoke to anybody about the attack, we seemed to be speaking two languages, on different levels about entirely different experiences.

I remember that as I sank down, I felt that I was sinking and rolling, sinking and falling. As I continued to sink, the darkness around me thickened. Fear took hold of me! I was aware that the speed of my fall was accelerating in relation to time. I stretched out my hand in the darkness, searching for something to grip in order to brake the force of acceleration. But all around me was only the void. I continued to fall at increasing speed. I surrendered to my fate. I knew in another moment the impact would come. With a broken heart, I cried out, "From the depths I call to you o Lord ..." (Psalm 130).

The echo of my cry had hardly died away when I felt the force of my fall becoming slower. The fall turned into a soft gentle landing, until I was left hanging in the dark void. I took a breath. I strained my eyes and tried to find a focus; in every direction, I saw nothing. I shouted for help, but heard nothing, not even the sound of my own cry. I stretched out my hand to the sides to feel but there was nothing. I felt panic and fear of the absolute "nothing." I realized that I was hovering over the sea of unknown "nothingness."

Suddenly I sensed that every movement of mine, even the slightest motion, changed my position and propelled me upwards. I wanted to 
get out of there, to escape the oppressive darkness; I wanted to return and began to move my limbs madly. I rose quickly, and began to glide. The darkness became less dense, its colors lighter and lighter until light returned. There I was again. Everything was familiar. There was the door, the doorframe that I had grasped, and I again tried to hold onto them, lest I slip off for a second time. In the same moment, I noticed that someone was lying there on the floor in a contorted position. I stopped to look at him. I was astonished and bewildered, for I knew him. I recognized the person who lay there. He was none other than myself. Thus I was confronted with an enigma. I had to find out who was who. I looked again and again at myself and at the person resting there. I was bewildered and astonished, for I knew the person lying there better than I knew myself. I seemed strange in my own eyes. I was surprised to discover that I had no limbs, no body nor bodily form. I was nothing but an isolated monad which I hadn't known before.

What a difference there was between us! Which of us was the real "me"? He lay there inanimate, but I could move. I had will and feeling and the capacity for thought. It must be that I was detached from myself and $I$ was the real "me." Full of compassion, I left him and that place, and with a great leap, I soared upwards. Then I felt that I was growing larger. I was expanding, spreading wings, covering great distances. I slowed down and glided, hovering happily. How delightful it was to soar and hover! How wonderful it was and how wondrous the tranquility!

Suddenly I realized that I was not alone. Many like me began to appear, becoming more numerous minute by minute until there was no counting them. They were all in motion, ever taking on new forms, expanding, revolving, and contracting, in their movement, merging and penetrating, passing and affecting one another. I was already among them, pulled along in the great current of movement, streaming upwards.

I was surprised by the brilliance of a light that had no source. The light was itself myriads of flames and auras, tints and hues. I touched aura after aura, flame after flame, each twisting and growing larger, quivering and separating. They changed their shape and their very being. They became part of the endless stream. The sound, no less than the light, amazed me. An infinity of tones mixing together in their varied and independent movement, streaming in a powerful current through vast expanse, upwards. I was light. I felt good. I was happy to be there with them, among them. I was seized by a powerful yearning to rise. I longed to transcend, to merge with that exalted center that 
drew me upwards. It seemed so close that I could have reached it in no time. But despite all my efforts, I could not reach it. I decided to ask the one nearest me the way there. But I was speechless. Still to my amazement he understood me without speaking and without words. Through thinking alone, we understood one another. He explained to me that there is no "up" and no "down." There is no space and no timeno dimension and no measuring. The way to the desired goal I longed for was the way of will and feeling and awareness. I understood!

Then I realized that $I$ was a different being in a new reality; a window had been opened for me to see the meaning of continuous, changing creation. I realized that I existed in a reality in which the laws of nature did not exist. All this wondrous activity was motion of different elements changing their being and creating in harmony a wondrous majestic symphony of kinetic movement.

Then I knew that I must distinguish between what was and what is. I remembered that self of mine, that had been.

I felt sorry, for I knew that he could not stand such mystic experiences without being hurt. I felt a need to return to him, to apologize, to explain to him that there are no compromises, that we must separate...

I turned to my body. On the way, I saw a most unusual sight in this new present reality: a steep hill glistening conspicuously above an area of mist. I stopped to look at it. I felt as if I were standing on solid ground. I noticed again my hands and feet, and became like my former "self." I tried to fly upwards but I couldn't. I had to walk. As I approached the hill, I noticed somebody was standing on the peak. I looked at him and recognized him. It was my father. A few paces behind him stood my brother, silent, smiling and looking at the two of us.

Father looked at me with his penetrating eyes and serious expression and in a voice of silence asked of me, "What are you doing here?"

I ignored his question and asked of him, "Please, Father, help me, stretch out your hand and pull me up." He asked again, "What are you doing here?" I answered, "I brought tools with me. Black paints and brushes. I want to paint and to engrave on the rock of this hill the verse 'Remember, you shall love the stranger, the orphan and the widow'" "What nonsense," he said. "These words have been written in the Book for thousands of years."

"It is true," I replied, "but parchment and ink are material things. How can material objects convey a spiritual idea? However, if I engrave a pure black color on this radiant white hill, it will glow like black fire on white fire and with such tremendous force that it will radiate out and cause the idea to enter in every heart, and every soul." 
Father's face grew furious and he reproached me, "You and your foolishness! Now? At this time? The hour is very late. Go back, my son, lest it be too late."

I straightened up and stretched. I stood on the tips of my toes. I raised my two hands and shouted, "Father, give me your hand-help me."

He did not respond. I lost my balance. I slipped and fell. A burning pain paralyzed my feet. I turned my head. I looked at Father. A gentle smile passed over his lips and his image began to dissolve and disappear, as well as my brother's image. I could no longer fly, nor even walk, and I began to crawl.

Crawling caused me tremendous pain, but I made progress. Suddenly I saw my body. I held it by both arms-its hands in mine, its eyes in mine. I held fast, tenaciously. I didn't say a word. In my ear, my father's words echoed, "Go back, lest it become too late." $\mathrm{My}$ senses clouded and I was lost in the darkness ...

Days passed. Already I could make out the people around me. I could speak, answer, respond. I lay in the hospital but my heart was there, far away. I yearned to return to that glorious tranquility, to that purity and splendor.

One day, a man dressed in a white cloak entered my room. He introduced himself as the treating physician in the intensive care ward. He asked me how I was and asked, by the way, if before the attack, I had done any physical work, or whether I had made any special physical effort, if I had climbed up a ladder, if I had painted my house in preparation for the holiday. I answered in the negative and I asked him to explain his questions. He said that when I was unconscious I mumbled about colors, about climbing, and many other words that he didn't understand. He was not the only one. Other doctors came and asked. My answers to them were all negative. They said I was unconscious. Was that really so? I knew and understood what I had seen and experienced. I felt I had achieved the revelation of a new truth. A different reality had been revealed to me. But I did not reveal these secrets of my heart to anyone. I was afraid that I would seem misleading.

Since then much time has passed. At first I was fearful. I needed emotional support. I sought solid ground to lean upon, something to hold onto. I consulted a psychiatrist. I turned to a rabbi, because my soul was stirred up in torment. In time, my spiritual turmoil subsided. I learned to live, and preserve my sanity. I must admit that in the end, I was altered, or I changed.

\section{Commentary}

There are a number of points worthy of commentary. In the original Hebrew, the account is written in evocative, lyrical style, full of allu- 
sions to many Biblical, Kabbalistic and other classical Hebrew sources. These allusions convey to the Hebrew reader a range of associations and doctrines beyond the scope of this translation. For example, the allusion to "white fire on black fire" refers to a well-known Jewish legend that states that Moses on Mount Sinai received the Ten Commandments originally in such a fiery form. Similarly, the phrase "absolute 'nothing'" is derived from Kabbalistic discussions about the nature of creation, specifically the doctrine of ex nihilo, creation of the world out of absolute nothing. In a similar vein, the description "no body, nor bodily form" is a quote from a well-known hymn, based on Maimonides's thirteen articles of faith, which describe the Almighty as having "no body, nor bodily form." To the Hebrew reader, this is an explicit hint at the depth of the mystical quality of the experience.

These numerous untranslatable allusions, however, seem particularly appropriate to the task of describing a mystical or near-death experience. They point the way to "what is ineffable," bridging the gap between the experience and the written (or spoken) word. In this manner, the text points beyond itself, to where "there is no 'up' and no 'down' ... no space and no time ... in a reality in which the laws of nature did not exist."

Chaim Ralbag grew up in one of the ultra-orthodox communities of Jerusalem (Simon, 1978). He is a descendant of 18th-century Lithuanian Jewish immigrants, who have continued to preserve a pious lifestyle based on twin poles of study and prayer. Although Ralbag abandoned this lifestyle while a young man, he was nevertheless immersed in the study of religious texts. Unlike various Hasidic groups, which are overtly mystical in their religious orientation, the group to which Ralbag belonged prided itself on being of a more rational outlook. Nevertheless, he was exposed in his youth to various written and oral traditions of near-death experience equivalents.

The best known of these traditions are recorded in the Book of Splendour, in Hebrew Zohar. This volume remains the most important and influential text in Jewish mysticism. Gershom Scholem (1977), the great student of Jewish mysticism, has established that the book in its present form derives from medieval Spain, but also that certain notions may derive from Rabbi Shimon bar Yọchai, a second-century teacher, to whom the volume is traditionally attributed.

The mystery of death plays an important role in the Book of Splendour. In the text, various traditions concerning the fate of the dying person and his soul are discussed.

The best known account of a near-death experience equivalent (known to Ralbag) occurs, it is said, at the moment a man is dying. 
Adam, the First Man, appears. Upon seeing this apparition, the dying man cries out, "It is because of you that I must die." To which Adam replies, "Yes, I did sin once, a sin for which I was severely punished. But, you, my son, have sinned not once, but many times." Adam proceeds to show the man a list of misdeeds and concludes, "There is no death without sin."

Another tradition does mention seeing relatives now deceased as a sign of impending death. A certain Rabbi Isaac, afraid that he was about to die, came to Rabbi Shimeon, who asked him:

Have you this day seen the face of your father? For we know that when the hour comes for a man to leave this world, he finds himself surrounded by his father and his relatives, and he looks at them and recognizes them, and sees all who were his companions in this world, and they escort his soul to the new abode it is to have ... (Scholem, 1977, p. 53)

Presumably because Rabbi Isaac had not yet seen his father, he was not yet thought to be near death. Shortly after, Rabbi Isaac did see his father in a dream, and he was informed that but for Rabbi Shimeon's request, Rabbi Isaac's time to die would have come.

Further, Rabbi Isaac was informed that "when a man's soul leaves him, it is met by all his relatives and companions from the other world, who guide it to the realm of delight and the place of torture" (Scholem, 1977, p. 57). The worthy man and the sinner are thus taken to see their respective abodes. Indeed, it is said that the soul of dying person makes nightly voyages, for 30 days prior to his death, to inspect his place in the "world to come." During the seven days after death, the soul goes back and forth from grave to house, mourning for its body. Other accounts describe the process as the soul departing from the body limb by limb. The common theme in all these accounts concerns reward and punishment in the afterlife.

That escatological concern with divine recompense is strikingly absent in Ralbag's account. The one scene in Ralbag's account that is relevant to the traditional near-death material concerns the meeting with his father. Chaim, the son, appears as a well-intentioned quixotic individual, while his father is presented as a stern patriarch. The meeting between son and father could be a sign of impending death. The father's angry question, "What are you doing here?" might be understood in one of two ways. As in the Book of Splendour, the visage of his father might be taken as an indication of his fate in the world to come, a fate his father might very well question, since Ralbag, the son, did deviate from the ways of his father. On the other hand, the meeting 
with father might be akin, as it seems to be in Ralbag's mind, to the meeting reported above between Rabbi Isaac and his father. In this case, the meeting of father and son is an indication that "the decree of death" has narrowly been averted. In either case, this meeting can be seen against the cultural genre presented by the Book of Splendour.

One feature typical of near-death experiences is missing from the Ralbag account. It is the "panoramic review of one's life." In this case as well, the tradition may illuminate the absence, for according to the Zohar, it is not the dying person but God Himself who makes the review:

When God has decided to receive back a man's spirit, he passes in review all the days of the man's life in this world. And happy the man whose days draw near to pass before the King without blame, with not a single one rejected on account of any sin therein. (Scholem, 1977, p. 60)

Otherwise, the account is a remarkably rich one, including almost all of the features described by Moody (1975). It includes out-of-body experiences, floating and moving through the darkness, feeling of intense peace, even exhilaration, awareness of an extraordinary light and sound, and meeting with other presences, including "spirits" of loved ones, in this case, father and older brother, who instruct him to return to life. Indeed, if there is a practical function to this near-death experience, it seems to provide for a reunion of body and spirit, after the two have been temporarily cut adrift.

Unknown to Ralbag, he had a fairly typical near-death experience, as described in the scientific literature. It is conceivable that the torment he described subsequent to his experience derived from his inability to integrate and/or relate this strange encounter with some pre-existing cultural form. Rather, I am suggesting his confusion was in part due to the lack of overall congruence between these near-death traditions of his native culture and what he actually experienced. That his implicit cultural expectations were imperfectly met led him to be fearful "to reveal these secrets of my heart to anyone ... because my soul was stirred up in torment."

I hope I have suggested how the study of individual near-death experiences can profit by viewing them against the available cultural genres or frames. The study of pre-existing religious and folk traditions concerning near-death experiences, or equivalents, is an endeavor worthy in its own right. Such traditions often serve to guide the initiate through an otherwise baffling, even disturbing, encounter. 
When a person's experience significantly deviates from these cultural norms, then the individual is likened to the man with a map for a country different from the one in which he finds himself. One may persist in using the incorrect guide despite the terrain; or one may eventually throw away the map and begin to explore the country on one's own. But between those two positions, there is a moment of panic in which one comes to realize that the inherited tradition is not a useful guide at all. Ralbag, having abandoned the ways of his Fathers, yet having no other model of his near-death experience, I suggest underwent just such a moment of panic.

\section{References}

Counts, D. A. (1983). Near-death and out-of-body experiences in a Melanesian society. Anabiosis, 3, 115-135.

Moody, R. A. (1975). Life After Life. Covington, GA: Mockingbird.

Ring, K. (1980). Life at Death: A Scientific Investigation of the Near-Death Experience. New York, NY: Coward, McCann \& Geoghegan.

Scholem, G. (1965) On the Kabbalah and Its Symbolism. New York, NY: Schocken.

Scholem, G. (1977). Zohar: The Book of Splendour. London, England: Rider.

Simon, R. (1978). Continuity and Change: A Study of Two Ethnic Communities in Israel Cambridge, England: Cambridge University Press. 